\title{
STUDIES IN THE LIVERWORT FAMILY METZGERIACEAE (METZGERIALES) FROM SOUTHERN AFRICA. 1. METZGERIA NUDIFRONS STEPHANI AND A KEY TO THE SPECIES
}

\author{
NONKUlULO PHEPHU \& JACQUES VAN RoOY
}

\begin{abstract}
This is the first of several projected articles on the taxonomy of southern African Metzgeriaceae H. Klinggr. A brief history of the genus Metzgeria Raddi in southern Africa, the only local representative, is presented. Family and genus descriptions, as well as a key to the species, are provided. Of the seven species currently recognized in southern Africa, M. nudifrons is the only species with gemmae on the dorsal surface of the thallus. It is also characterized by the distinctly broad costa, hairy male branchlets as well as single and straight hairs on the ventral face and margins of the thallus. Metzgeria nudifrons is described, illustrated and its geographical distribution mapped.
\end{abstract}

Key words: Metzgeriaceae, Metzgeria nudifrons, South Africa, gemmae, taxonomy

Nonkululo Phephu \& Jacques van Rooy, National Herbarium, South African National Biodiversity Institute (SANBI), Private Bag X101, Pretoria 0001, South Africa;. e-mail: n.phephu@sanbi.org.za \& j.vanrooy@sanbi.org.za

\section{INTRODUCTION}

The family Metzgeriaceae H. Klinggr. consists of 2-4 genera world-wide (Wigginton 2004). It is the only family in the order Metzgeriales that is primarily epiphytic with most species growing on tree bark or living leaves. Some species may also grow on damp rocks or rarely on soil. They generally grow in tropical to temperate rain and mist forests in mountainous areas. It differs from the other southern African families of the order Metzgeriales (Perold 1999) in producing hairs on the ventral side and along the margins of the thallus as well as the midrib, gemmae often present, male branch without and female branch with hairs, elaters 1-spiral, capsule wall 2-striated and archegonial neck reduced.

In southern Africa, the family is only represented by one widespread genus, Metzgeria Raddi. Metzgeria species are often intermixed with other corticolous mosses and most are epiphytic. They grow in wetter parts of forests or open habitats, rarely on soil but on tree trunks, branches, twigs, living leaves, and rocks.
Metzgeria is a large genus of $60-80$ validly published species world-wide, with South America as its centre of diversity with about 50 recognized species (Wigginton 2004; So 2004). Out of eight recognized species in Africa, four are endemic to the continent (So 2004) and seven occur in southern Africa. The basic morphological uniformity of Metzgeria has become a reason to group rather than split the species. Recent revisions (e.g., So 2002, 2004) have therefore resulted in a decrease in species numbers. In southern Africa the genus ranges from coastal areas of the southern Cape and Kwa-Zulu Natal, inland to Swaziland and extending to the Wolkberg area in Limpopo.

The aim of this series is to revise the family Metzgeriaceae in southern Africa (South Africa, Lesotho, Swaziland, Botswana, Namibia) in continuation of a revision of all liverworts in the region (Perold 1999). The first paper in the series deals with the taxonomy and nomenclature of Metzgeria nudifrons Stephani, the only species with gemmae on the dorsal surface of the thallus. 


\section{HISTORICAL NOTES}

According to Pócs (1993, and references therein), the African Metzgeriaceae were reviewed first by Vanden Berghen (1948), who described two new species and supplied a key to the Central African taxa. Kuwahara (1973, 1983, 1986) described new species, new records, and placed several African taxa in synonymy. As a result, the known distribution of several African Metzgeria species widened considerably. At the time of Pócs's (1993) study, 21 Metzgeria species were known from sub-Saharan Africa, of which 14 occurred in Central and East Africa. He included a tentative key to species, declaring that the African species of Metzgeria are badly in need of an up to date revision. The recent revisions by So $(2002,2004)$ have brought a measure of stability to the taxonomy and nomenclature of Metzgeria in the region. However, she did not examine Metzgeria specimens in the National Herbarium, Pretoria (PRE), which houses the largest collection of southern African bryophytes, but only some southern African collections in overseas herbaria.

Sim (1926) published the first synopsis of the family Metzgeriaceae in South Africa. He recognized four species of Metzgeria, namely M. perrotana Stephani, M. furcata (L.) Corda, M. conjugata Lindb. and M. muscicola Stephani. The next revision of southern African Metzgeriaceae was by Arnell (1963) who recognized 13 species in the region (South Africa, Swaziland, Lesotho and Namibia): M. vialacea (Ach.) Dumort, M. elliotii Stephani, M. capensis S. W. Arnell, M. tabularis Stephani, $M$. perrotana Stephani., M. hamata Lindb. (illegitimate), M. camerunensis Stephani, M. madagassa Stephani, M. limbatosetosa Stephani, M. nudifrons Stephani, M. quadrifaria Stephani, M. saxbyi Pearson and $M$. muscicola Stephani. Most of these species are now synonyms of the seven currently recognized species in the region while $M$. violacea does not occur in the southern African region (So 2004; Perold 2006). Like Sim, Arnell did not list the specimens examined.

Veltman (1998) revised the southern African species of Metzgeria for her M.Sc. degree but did not resolve the nomenclature of the taxa. She recognized 13 species in southern Africa, and subsequently described a new species, $M$. nicomariei Veltman \& Potgieter (Veltman et al. 2000), which was reduced to synonymy of $M$. furcata by So (2004).

In the latest checklist of South African liverworts, Perold (2006) accepted five species of Metzgeria, namely $M$. consanguinea Schiffner, M. furcata, M. leptoneura Spruce, M. madagassa and $M$. nudifrons, based on the revision of So (2004), who also recognized M. quadrifaria from Lesotho. Phephu and van Rooy (2011) confirmed the occurrence of M. saxbyi in Swaziland and the Western Cape.

\section{MATERIALS AND METHODS}

Traditional morphological-anatomical methods were employed to study the species. Microscope slides were prepared using standard bryophyte preparation methods employing Hoyer's Mounting Medium (Magill 1981). Specimens studied were obtained from PRE and BM (herbarium acronyms according to Holmgren et al. 1990).

\section{TAXONOMIC TREATMENT}

\section{Metzgeriaceae H. Klinggr.}

Höh. Crypt. Preuss.: 10. 1858. Sim (1926), Arnell (1963), Schuster (1992), Wigginton (2004), Costa (2008).

TYPE GENUS: Metzgeria Raddi

Plants thalloid, yellowish green. Thallus narrow, thin, prostrate, erect or pendent and flattened, either irregularly or dichotomously branched; lamina 1-stratose, apex truncate (or obtuse), margins bearing bristle-like hairs; costa well defined, with large epidermal cells; hairs bristle-like, on thallus margins and ventral surface of costa and thallus. Oil bodies absent or very small, homogeneous. Ventral scales absent. Asexual reproduction by gemmae. Dioicous or monoicous. Specialized male and female branches (gametangia) on very short branchlets scattered along the ventral side of the costa, antheridia inside a globose sac, archegonia hidden under a thallus flap, sporophyte surrounded 
by fleshy, hairy calyptras; capsule spherical to ovoid, splitting into four valves when mature, walls 1-2-stratose; elaters single-spiral, attached to elatophore at valve apices. Spores small, minutely papillose.

\section{Metzgeria Raddi}

Jungermanniogr. Etrusca: 34. 1818. Schuster (1992), So (2004), Wigginton (2004), Costa (2008).

LECTOTYPE: M. glabra Raddi, nom. illeg. [三 Jungermannia furcata L., M. furcata (L.) Dumortier], fide So (2004).

Plants bright to pale yellowish green, dried herbarium specimens sometimes blue-green or whitish green. Thallus thin, linear, 4-60 mm long, up to $2.5 \mathrm{~mm}$ wide; branching irregular or dichotomous, sometimes with intercalary branches arising from ventral face of costa; apex obtuse or acute, retuse or truncate, sometimes with slimepapillae; margins plane or recurved, border absent; costa well defined, composed of rows of large, thin-walled dorsal and ventral epidermal cells and thick-walled internal medullary cells; wing 8-32 cells from midrib to thallus margin, cells hexagonal, thin-walled, trigones absent or minute. Hairs present, one-celled, on thallus margins, ventral side of costa and often on ventral surfaces of lamina, single or paired (geminate), straight or curved. Gemmae borne on margins or dorsal face of thallus, circular or oblong, plane or concave. Dioicous or monoicous. Male branches specialized, borne on very short, naked or hairy branchlets from ventral side of costa, inrolled to form a globose sac enclosing the antheridia. Female branches obcordate or oblong, flat or folded, very hairy. Calyptra clavate, densely hairy, thick, enclosing sporophyte. Capsule spherical, shortoval, on slender seta, splits into four valves when mature, often with terminal tufts of hair on the valves. Elaters long, slender, 1-spiral, partly loosening, reddish brown. Involucre if present, elongated, oblong.

In southern Africa Metzgeria grows on bark of trees and shrubs, shaded rock or soil in forests and wooded kloofs or mountain streams, at elevations of 300-2134 m.
Provisional KeY to THE SPECIES OF METZGERIA IN SOUTHERN AFRICA

1. Plants monoicous, marginal hairs single ....... $\ldots \ldots \ldots \ldots \ldots \ldots \ldots \ldots \ldots \ldots \ldots \ldots \ldots$ saxbyi

1. Plants dioicous, marginal hairs single or geminate .......................... 2

2. Gemmae only on dorsal surface of thallus (best seen on fresh material, could be lacking on old herbarium material), discoid and oval; costa very broad

M. nudifrons

2* Gemmae often absent, if present on margins of thallus; costa fairly narrow .......... 3

3. Hairs abundant, throughout margin and ventral costa, paired, distinctly curved; thallus markedly convex ........................ Meptoneura

3. Hairs sparse to often absent, on ventral face of costa, curved or straight; thallus not markedly convex . . . 4

4. Thallus with tapered and acute apices (dimorphic); gemmae concave .........M. consanguinea

4. Thallus with obtuse apices only, furcate; gemmae fairly flat ................ 5

5. Costa of 2-3(-5) dorsal and 3-(4-6) ventral cells, thallus margins sometimes inrolled ........... ...................... quadrifaria

5. Costa of 2(-3) dorsal and 2-3(-5) ventral cells, thallus margins plane $\ldots \ldots \ldots \ldots \ldots \ldots 6$

6. Marginal hairs usually single, rarely geminate (less than 5\%); thallus often sparsely hairy; hairs often straight, marginal and costal hairs often about same length; costa of 2 dorsal and 2(3-4) ventral cells ....................... M. furcata

6. Marginal hairs often geminate (more than $80 \%$ ); thallus hairy to conspicuously so; hairs curved, often shorter at margins; costa of $2(-3)$ dorsal and 2-3(-5) ventral cells ......... M. madagassa

Metzgeria nudifrons Stephani

Fig. 1

Hedwigia 31: 126. 1892. So (2004), Wigginton (2004). TYPE: SOUTH AFRICA, Cape Town, Rehmann s.n. (LECTOTYPE, G 00045406!; ISOLECTOTYPE, BM!).

Metzgeria brunnthaleri Stephani in Brunnthaler, Denkschr. Kaiserl. Akad. Wiss., Math.-Naturwiss. K1. 88: 725 (1913). TYPE: SOUTH AFRICA, Natal, 1909, Brunnthaler s.n. (HOLOTYPE, G 00045398!).

Plant bright to dark green, sometimes bluish in herbarium specimens, fairly robust. Thallus rather large, 15-40 mm long, 1.0-1.5 mm wide, weakly convex; branches dichotomous, sometimes 

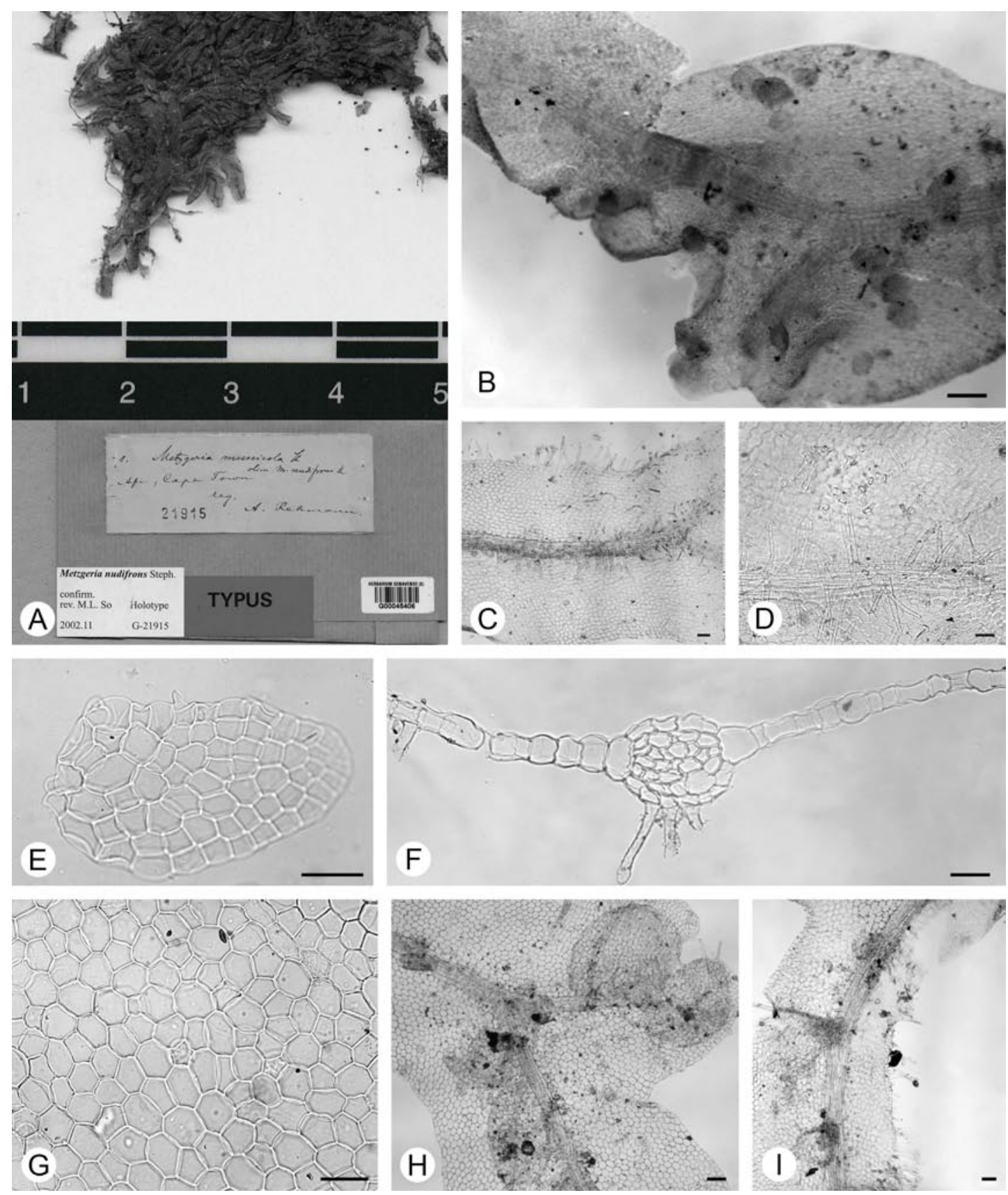

Fig. 1. Metzgeria nudifrons Stephani. A - specimen and original label of the lectotype, B - dorsal surface of thallus with gemmae, $\mathrm{C}$ - ventral surface of thallus showing ventral and marginal hairs, D - ventral surface of thallus showing hairs, E - gemma, F - cross section of midrib, G - median laminal cells, H - male branch, I - female branch. A from Rehmann s.n. (G 00045406); B, D \& F from Bosman CH210 (PRE); C \& H from Sim 1488; E \& G from MacOwen s.n. (BM); I from Farquhar CH1439 (PRE). Scale bars: A in cm; B, C, H \& I = $0.04 \mathrm{~mm}$; D \& F $=0.1 \mathrm{~mm} ; \mathrm{E} \& \mathrm{G}=0.2 \mathrm{~mm}$. 
with ventral adventitious branches, nude dorsally, ventral face hairy; wing 18-32 cells from midrib to margin; apex truncate, retuse or rounded, often with 1-4 slime papillae at apex tip; margins plane, frequently undulating especially near apex. Costa $125 \mu \mathrm{m}$ wide, prominent; dorsal cells (2)3-7; ventral cells 3-10(11); medullary cells 16-29, in 4 rows, thick-walled. Laminal cells $25-36 \times$ 35-54 $\mu \mathrm{m}$, smooth, thin walled. Hairs single, rarely geminate, straight, $0.10-0.14 \mathrm{~mm}$, sparse to abundant, on thallus margins and ventral face of thallus and costa. Gemmae on dorsal face of thallus, up to $0.47 \mathrm{~mm}$ long, disciform, suborbicular or oval, flat, occasionally with short curved hairs on margins. Dioicous. Male branches $0.2-0.6 \mathrm{~mm}$ wide, subglobose. Female branches $0.1-0.6 \mathrm{~mm}$ long, cordate, hairy, hairs 100-200 $\mu \mathrm{m}$ long. Calyptra about $250 \mu \mathrm{m}$, pyriform, hairy.

Metzgeria nudifrons is an epiphyte and grows on the bark of trees and shrubs, at elevations of 457 to $2134 \mathrm{~m}$. It is endemic to Africa and is widespread in coastal and inland forests of Limpopo, KwaZulu-Natal, Western Cape and Eastern Cape Provinces of South Africa (Perold 2006) (Fig. 2). It was first reported from Lesotho by Hodgetts et al. (1999). The species is also known from Cameroon, Democratic Republic of Congo, Madagascar, Malawi, Tanzania, Uganda, Zambia and Zimbabwe (So 2004; Wigginton 2009).

SPECIMENS EXAMINED. (Provinces and collectors in alphabetical order). SOUTH AFRICA. EASTERN CAPE: Grahamstown, 3326BC, Mar. 1910, Farquhar CH1439

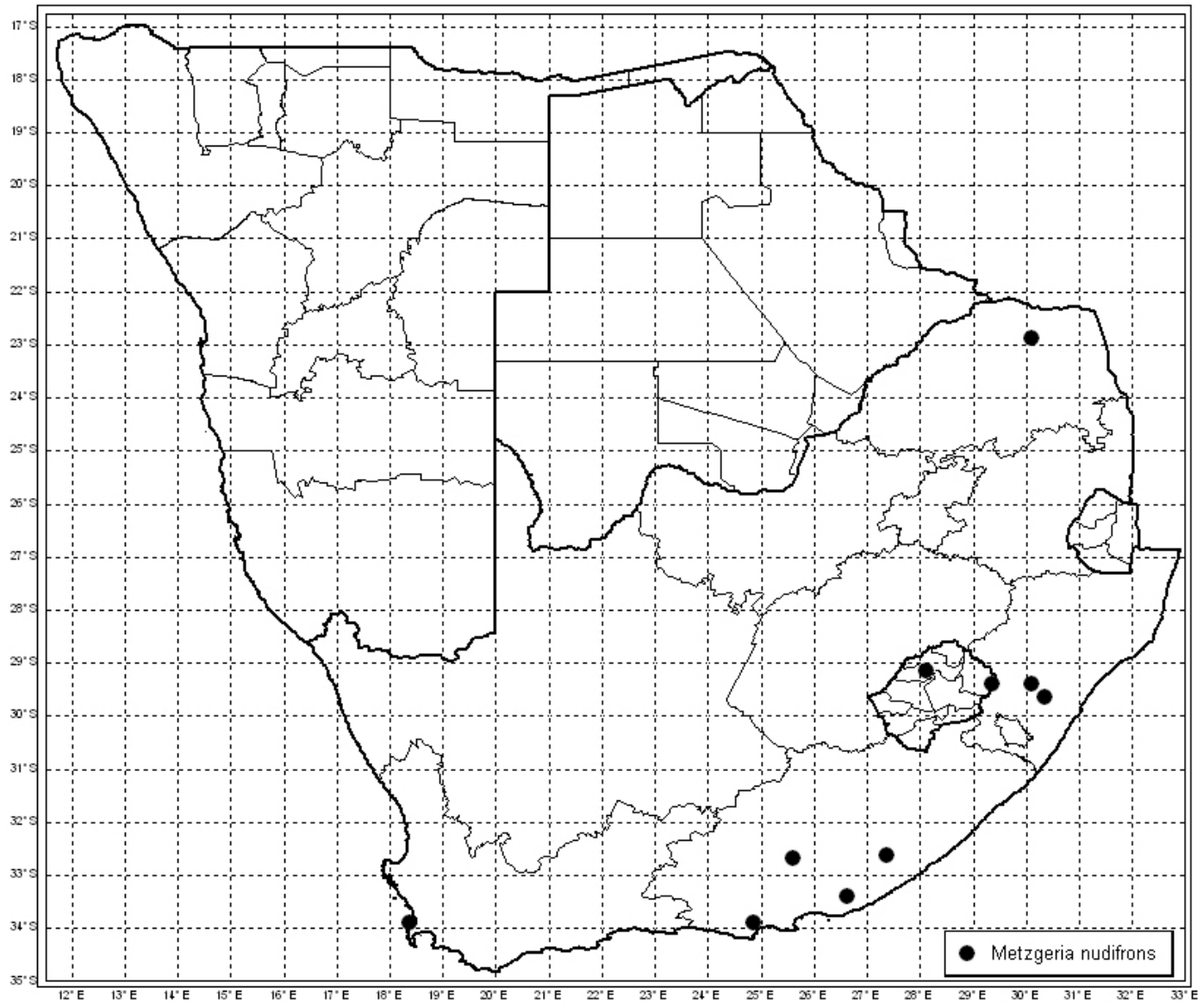

Fig. 2. Known distribution of Metzgeria nudifrons Stephani in southern Africa. 
(PRE); Dohne Hill, Kaffraria, 3227CB, 4500 ft., 1889, Sim CH1431 (PRE). KwAZULU NatAL: Pietermaritzburg, near Botanical Gardens, 2930CB, Aug. 1920, Gibbs CH1416 (PRE); Pietermaritzburg, Hilton Road, 2930CB, 4000 ft., May 1921, Sim CH1411 (PRE); Underberg, Giants Castle, 2929AD, 7000 ft., Dec. 1915, Symons CH1415 (PRE); Pietermaritzburg, Nottingham Road, 2930AC, Apr. 1917, Van der Bijl CH1430 (PRE). LIMPOPO: Mesina, Piesanghoek, Zoutpansberg, on bluegums, 2230CC, 3 May 1929, Bosman 4415, CH210 \& CH1424 (PRE). WESTERN CAPE: Kirstenbosch, Skeleton Ravine, 3318CD, 10 Sept. 1951, Arnell 579 (PRE); Cape Town, Blinkwater Ravine, above Camps Bay, 3318CD, 1500-3000 ft., Feb. 1917, Bews CH1423 (PRE); Cape, Ecklon s.n. (BM); Boschberg, 3225DA, MacOwan s.n. (BM); Table Mountain, Disa Ravine, 3318CD, 2500 ft., Dec. 1919, Sim 1488 (PRE). No PRECISE LOCALITY: 1960, Wager CH3837 (PRE); Transvaal, McLea 58 (BM). ZIMBABWE. Zimbabwe Ruins, Jul. 1920, Sim CH1418 (PRE); S. Rhodesia, 3000 ft., Jul. 1930, Sim 1437 (PRE).

\section{DISCUSSION}

The species of Metzgeria are very similar in appearance and it is difficult to correctly identify specimens, especially if the material is scanty (e.g., a few strands of sterile thalli without gemmae). Most species are dioicous, plants remain in the vegetative stage for a long time and sporophyte features fail to reveal themselves. The exact time of sporophyte production in southern Africa is unknown (Veltman 1998). Sterile material of Metzgeria can be easily misidentified as characters like costal epidermal cells and hair placement and presence occur sporadically. Marginal and costal hairs are a difficult character to use when the material is very old as these get broken with age.

The most useful diagnostic characters in defining southern African species of Metzgeria are the placement and morphology of gemmae, the number of epidermal cells on dorsal and ventral faces of costa (best seen in cross section), and the morphology and distribution of marginal and costal hairs on the thallus, all used in combination. According to So (2004) the distribution of hairs (single or paired) is less significant as all African species are capable of producing both single and paired hairs. In African species this character is variable, from hairs absent, sparsely hairy to hairy, except for one species, M. leptoneura, which almost invariably has abundant hairs throughout the margins and ventral side of the costa. Metzgeria furcata and $M$. madagassa are the most difficult species to separate as most characters are very similar.

Metzgeria nudifrons was last revised for South Africa by Arnell (1963). In her revision of African taxa, So (2004) designated the Rehmann specimen in G (Fig. 1) as the lectotype of $M$. nudifrons. The species is separated from other species of Metzgeria in southern Africa by the disk-shaped gemmae on the dorsal surface of the thallus, distinctly broad costa, hairy male branchlets and single and straight hairs on ventral face and margins of the thallus. Gemmae are often absent on old herbarium specimens, if present they often lack marginal hairs. The widespread M. crassipilis (Lindb.) A. Evans also produces gemmae on the dorsal surface of the thallus, but apparently differs in the straight rather than curved hairs of the gemmae (So 2004). However, this character is not very useful in southern Africa as hairs are rarely found on the gemmae, probably because of the age of the herbarium specimens. In Africa, M. crassipilis is only known as far south as Malawi. The costa of $M$. nudifrons seems to be broader on southern African plants than those from the northern African region, with the dorsal, ventral and medullary cells of the costa up to 7 , 11 and 29 cells respectively.

The geographical distribution of $M$. nudifrons (Fig. 2) is similar to species of the Afromontane Forest Element (van Rooy \& van Wyk 2011). This element consists mostly of (sub-)tropical forest mosses of the Orders Isobryales, Hookeriales, Thuidiales and Hypnobryales. The Afromontane Forest Element is centered in the Drakensberg of KwaZulu-Natal and the escarpment of Mpumalanga and Limpopo, but ranges all the way down to the Western Cape.

The bryofloristic area in which $M$. nudifrons occurs is known as the Afromontane Region (van Rooy \& van Wyk 2010), characterized by the presence of Afromontane forests and the abundance of pleurocarpous mosses. 
ACKNOWLedgements. We wish to thank Professor Braam van Wyk of the University of Pretoria for the use of his microscope laboratory, Ms Elizma Fouche for editing the images and Mr. Thabo Masupa for creating the distribution map. We would also like to thank Dr. Michelle Price for a link to the G database of type images. The image of the Metzgeria nudifrons lectotype specimen ( $\mathrm{G} \mathrm{00045406)}$ is published with the permission of the Conservatoire et Jardin botaniques de la Ville de Genève.

\section{REFERENCES}

ARNELL S. 1963. Hepaticae of South Africa. Swedish Natural Science Research Council, Stockholm.

Costa D. P. 2008. Metzgeriaceae (Hepaticae). Fl. Neotrop. Monogr. 102: 1-169.

Hodgetts N. G., Matcham H. W. \& Duckett J. G. 1999. Bryophytes collected in Lesotho, the Natal Drakensberg and the Orange Free State, southern Africa. J. Bryol. 21: 133-155.

Holmgren P. K., Holmgren N. H. \& Barnett L. C. (eds) 1990. Index Herbariorum. Part 1: The Herbaria of the World. New York Botanical Garden, New York.

KUWAHARA Y. 1973. Further notes on the production of vegetative thallus structures by female involucres of Metzgeria, and a new species of Metzgeria. Bryologist 76: 566-571.

KUWAHARA Y. 1983. Metzgeria vandenberghenii, sp. nov. du Zaire et quelques autres Metzgeria (Hepaticae) reconnues récemment ena Afrique. Bull. Jard. Bot. Natl. Belg. 53: $67-73$.

KUWAHARA Y. 1986. The Metzgeriaceae of the Neotropics. Bryophyt. Biblioth. 28: 1-254.

MAgILl R. E. 1981. Flora of Southern Africa. Bryophyta. Part 1 Mosses. Fasc. 1 Sphagnaceae-Grimmiaceae. Botanical Research Institute, Department of Agriculture \& Fisheries, Pretoria.

Perold S. M. 1999. Flora of Southern Africa. Hepatophyta. Part 1: Marchantiopsida. Fascicle 1: Marchantiidae. National Botanical Institute, Pretoria.
Perold S. M. 2006. Hepatophyta. In: G. Germishuizen, N. L. MEYER, Y. STEENKAMP \& M. KEITH (eds), A checklist of South African plants. Southern African Botanical Diversity Network, Pretoria.

PhePhU N. \& VAN RoOY J. 2011. Note on the occurrence of Metzgeria saxbyi in southern Africa. J. Bryol. 33: 85.

Pócs T. 1993. Taxonomic Results of the BRYOTROP Expedition to Zaire and Rwanda 12: Metzgeriaceae, Plagiochilaceae, Lejeuneaceae (the non epiphyllous collections). Trop. Bryol. 8: 105-108.

SCHUSTER R. M. 1992. The Hepaticae and Anthocerotae of North America. 5. Field Museum of Natural History, Chicago.

SiM T. R. 1926. The Bryophyta of South Africa. Trans. Roy. Soc. South Africa 15: 1-475.

So M. L. 2002. Metzgeria (Hepaticae) in Australasia and the Pacific. New Zealand J. Bot. 40: 603-627.

So M. L. 2004. Metzgeria (Metzgeriaceae, Marchantiophyta) in Africa. New Zealand J. Bot. 42: 271-292.

VANDEN BERGHEN C. 1948. Contribution a l'étude des espèces africaines du genre Metzgeria. Bull. Jard. Bot. État Bruxelles 19: 37-49.

VAN ROOY J. \& VAN WYK A. E. 2010. The bryofloristic regions of southern Africa. J. Bryol. 32: 80-91.

VAN ROOY J. \& VAN WYK A. E. 2011. The bryofloristic elements of southern Africa. J. Bryol. 33: 17-29.

Veltman A. 1998. Contributions to the systematics of the southern African Metzgeriaceae (Hepatophyta). M.Sc. Dissertation, University of Pretoria, Pretoria.

Veltman A., Potgieter M. J. \& VAn WyK A. E. 2000. Metzgeria nicomariei, a new species of Metzgeriaceae from South Africa. S. African J. Bot. 66: 112-114.

WigGinTON M. J. 2004. E. W. Jones's liverwort and hornwort flora of West Africa. National Botanic Garden of Belgium, Meise.

WigGinTON M. J. 2009. Checklist and distribution of the liverworts and hornworts of sub-Saharan Africa, including the East African Islands. Tropical Bryology Research Report 8: $1-116$. 